\title{
CHEMICAL CHANGES IN SEA WATER OFF PLYMOUTH IN 1961
}

\author{
By F. A. J. Armstrong and E. I. Butler \\ The Plymouth Laboratory
}

Regular observations at International Hydrographic Station E I (lat., $50^{\circ} 02^{\prime} \mathrm{N}$, long., $4^{\circ} 22^{\prime} \mathrm{W}$.) were continued in $\mathrm{I} 96 \mathrm{I}$, and it is hoped that they will go on in the future although we have shown that they may not be typical of the area off Plymouth (Armstrong \& Butler, 1962 $b$ ). The observations in 1961 form part of some wider surveys, but we think it best to separate those for station E I and to report them in the same form as has been used in recent years (Armstrong, 1954, I955, 1957, I958; Armstrong \& Butler, 1959, 1960 $a, b$, I962a).

The methods of collection and analysis remain unchanged.

We wish to repeat our thanks to Lt.-Cdr. C. A. Hoodless, D.S.C., and the crew of R.V. 'Sarsia', and Capt. W. J. Creese and the crew of R.V. 'Sula' for help at sea.

\section{Temperature and salinity}

\section{RESULTS}

The vertical distribution of temperature during the year is shown in Fig. I, and integral mean concentrations for the water column of $70 \mathrm{~m}$ in Table $\mathrm{r}$. The lowest surface temperature was $10.07^{\circ} \mathrm{C}$ on Io January; the highest was I6. $15^{\circ}$ on I9 July. There was a temperature difference of about $0.6^{\circ} \mathrm{C}$ between the upper and lower levels in April, and by 24 May a marked thermocline at I $2 \mathrm{~m}$ had developed. It persisted during the summer and though well marked on I2 September had gone by 3I October. The salinity changed slowly and fairly regularly during the year, being at its highest $(35.33 \%$ ) on 21 February and decreasing during the spring and summer to $35.07 \%$ on 23 August, increasing thereafter. On I2 September the salinity of the upper $20 \mathrm{~m}$ was $35.12 \%$, and that of the deeper water $35.10 \%$, indicating the presence of two distinguishable water masses one above the other at the station.

\section{Phosphate}

The vertical distribution is shown in Fig. 2, and the integral mean concentrations in Table I. The maximum found during the year was $0.44 \mu \mathrm{g}$ atom P/1. on Io January and I4 December. This is unusually low, similar figures having been recorded only in I934 and I935 (Cooper, 1938) and in I948 and 1949 (Armstrong \& Harvey, 1950). After the spring growth of 


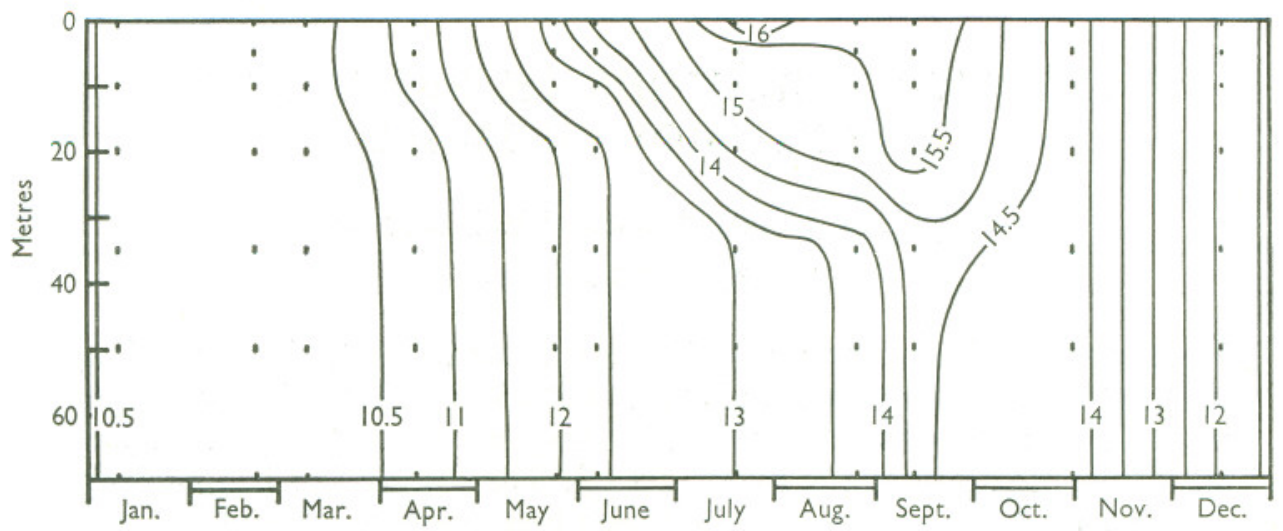

Fig. I. Vertical temperature distribution at International Hydrographic Station E I, 1961. Contour lines at $0.5^{\circ} \mathrm{C}$ intervals

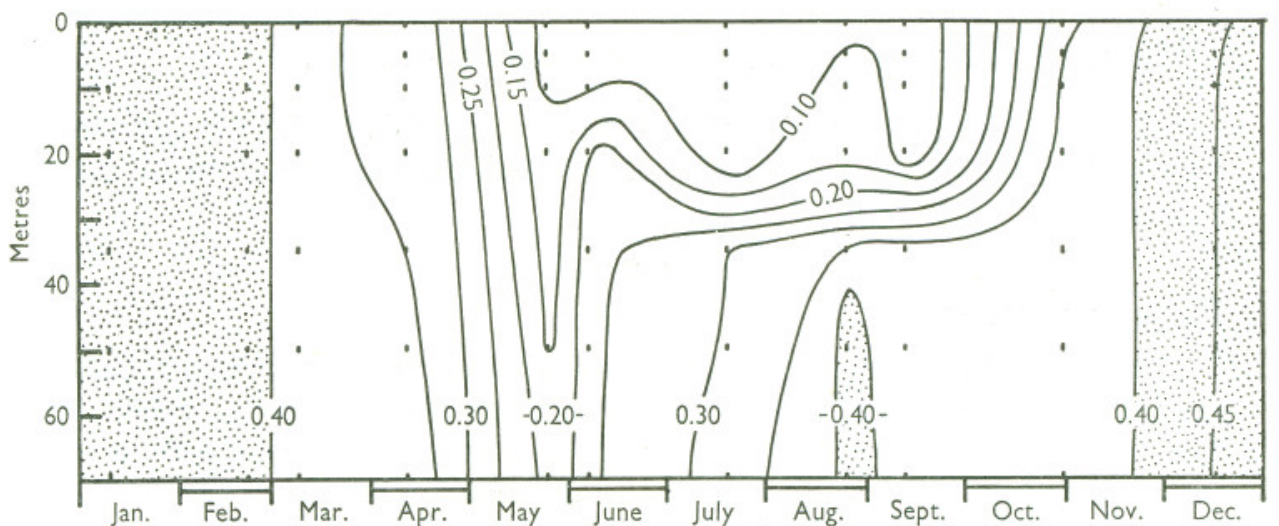

Fig. 2. Vertical distribution of phosphate at International Hydrographic Station E I, I96r. Contour lines at $0.05 \mu \mathrm{g}$ atom $\mathrm{P} / 1$. intervals.

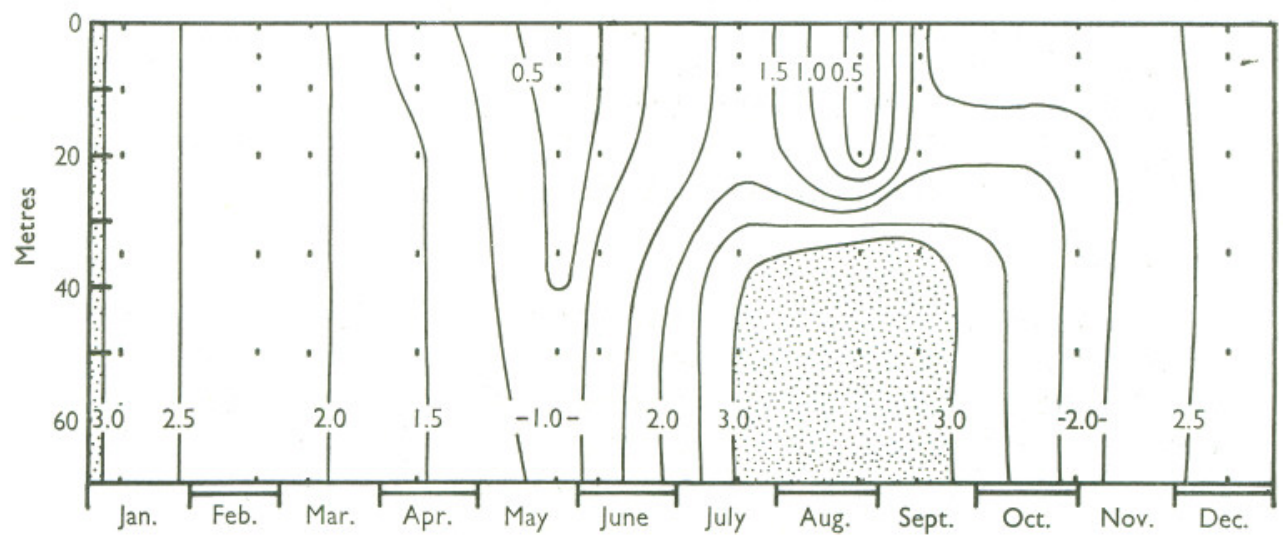

Fig. 3. Vertical distribution of silicate at International Hydrographic Station E I, 196I. Contour lines at $0.5 \mu \mathrm{g}$ atom $\mathrm{Si} / 1$. intervals. 
phytoplankton very low values were found on 24 May (integral mean $0.13 \mu \mathrm{g}$ atom $\mathrm{P} / 1$.). Low values in the upper layers persisted until I2 September. By 3I October the water column was uniform and concentrations increased until the end of the year.

\section{Total phosphorus}

Values for January, February and March are given in Table I. The maximum of $0.53 \mu \mathrm{g}$ atom $\mathrm{P} / \mathrm{l}$. in January and February was unusually low, although slightly lower figures had been found in I948 and I949, the first two years in which this determination was made.

\begin{tabular}{|c|c|c|c|c|}
\hline Date & $\underset{(\%)}{\text { Salinity }}$ & $\begin{array}{c}\text { Phosphate } \\
(\mu \mathrm{g} \text { atom } \mathrm{P} / 1 .)\end{array}$ & $\begin{array}{c}\text { 'Total } \mathrm{P} ' \\
(\mu \mathrm{g} \text { atom } \mathrm{P} / \mathrm{l} .)\end{array}$ & $\begin{array}{c}\text { Silicate } \\
(\mu \mathrm{g} \text { atom Si/1.) }\end{array}$ \\
\hline ro Jan. & $35 \cdot 38_{0}$ & 0.44 & 0.53 & 3.15 \\
\hline 2 I Feb. & 35.330 & 0.42 & 0.53 & I.95 \\
\hline 9 Mar. & $35 \cdot 32_{1}$ & 0.37 & 0.43 & $2 \cdot 07$ \\
\hline I I Apr. & $35 \cdot 26_{4}$ & 0.35 & - & I. 49 \\
\hline 24 May & $35 \cdot 150$ & 0.13 & - & 0.43 \\
\hline 6 June & $35 \cdot \mathrm{IO}_{9}$ & 0.20 & - & 1.09 \\
\hline I9 July & $35.09_{8}$ & 0.22 & - & 2.51 \\
\hline 23 Aug. & $35.06_{9}$ & 0.30 & - & $2 \cdot 07$ \\
\hline I2 Sept. & $35 \cdot \mathrm{II}_{0}$ & 0.26 & - & $2 \cdot 70$ \\
\hline 3I Oct. & $35 \cdot 232$ & 0.36 & - & I.92 \\
\hline I4 Dec. & $35 \cdot 30_{8}$ & 0.44 & - & $2 \cdot 66$ \\
\hline
\end{tabular}

\section{Silicate}

The vertical distribution is shown in Fig. 3 and the integral mean concentrations in Table I. The maximum found was $3.15 \mu \mathrm{g}$ atom $\mathrm{Si} / \mathrm{l}$. in January. Low values throughout the water column were found in May; these gave the unusually low integral mean concentration of $0.43 \mu \mathrm{g}$ atom Si/l. After this, silicate was very low in the upper layers during the summer (except in July) but high in the deeper water. On 3I October silicate was slightly higher in the uppermost $20 \mathrm{~m}$ than below, although the water column appeared to be uniform in its other properties. It will be seen in Table I that the total in the column was less than in September.

\section{Integral mean concentrations}

The spring decreases were: phosphate $0.2 \mathrm{I} \mu \mathrm{g}$ atom $\mathrm{P} / 1$., silicate, $2 \cdot 72 \mu \mathrm{g}$ atom $\mathrm{Si} / 1$. The decrease in phosphate is an unually small one.

\section{SUMMARY}

The results of analysis of sea water samples from the International Hydrographic Station E I ( $50^{\circ} \mathrm{Oz}^{\prime} \mathrm{N} ., 4^{\circ} 22^{\prime} \mathrm{W}$.) are given in graphical form and as integral mean values for the water column of $70 \mathrm{~m}$. Winter maximum values 
(in January) of $0.44 \mu \mathrm{g}$ atom phosphate $\mathrm{P} / 1$. and $0.53 \mu \mathrm{g}$ atom 'Total' $\mathrm{P} / 1$., with $3.15 \mu \mathrm{g}$ atom $\mathrm{Si} / 1$. were found. The phosphate and 'total' phosphorus concentrations were unusually low. The spring decreases were $0.2 \mathrm{I} \mu \mathrm{g}$ atom $\mathrm{P} / 1$. and $2 \cdot 72 \mu \mathrm{g}$ atom Si $/ 1$.

\section{REFERENCES}

Armstrong, F. A. J., I954. Phosphorus and silicon in sea water off Plymouth during the years 1950 to I953. F. mar. biol. Ass. U.K., Vol. 33, pp. 38I-92.

- 1955. Phosphorus and silicon in sea water off Plymouth during 1954. F. mar. biol. Ass. U.K., Vol. 34, pp. 223-8.

_ 1957. Phosphorus and silicon in sea water off Plymouth during 1955. F. mar. biol. Ass. U.K., Vol. 36, pp. 317-19.

— 1958. Phosphorus and silicon in sea water off Plymouth during 1956. F. mar. biol. Ass. U.K., Vol. 37, pp. 371-7.

Armstrong, F. A. J. \& ButLeR, E. I., I959. Chemical changes in sea water off Plymouth during 1957. F. mar. biol. Ass. U.K., Vol. 38, pp. 4I-5.

_ $1960 \mathrm{a}$. Chemical changes in sea water off Plymouth during 1958. F. mar. biol. Ass. U.K., Vol. 39, pp. 299-302.

- _ 1960 $b$. Chemical changes in sea water off Plymouth during 1959. F. mar. biol. Ass. U.K., Vol. 39, pp. 525-8.

__ I962 $a$. Chemical changes in sea water off Plymouth during 1960. F. mar. biol. Ass. U.K., Vol. 42, pp. 253-8.

- $1962 b$. Hydrographic surveys off Plymouth during 1959 and 1960. F. mar. biol. Ass. U.K., Vol. 42, pp. 445-63.

Armstrong, F. A. J. \& Harvey, H. W., I950. The cycle of phosphorus in the waters of the English Channel. F. mar. biol. Ass. U.K., Vol. 29, pp. I45-I62.

Cooper, L. H. N., 1938. Phosphate in the English Channel 1933-8 with a comparison with earlier years 1916 and 1923-32. F. mar. biol. Ass. U.K., Vol. 23, pp. 18I-95. 